\title{
96. 工学側から久た電気手術器の諸問題
}

電気手術器（電気メス）は，生体に大きな高 周波電流を印加し，電流の集中するメス刃先付 近での放電を利用して, 生体組織の切開や凝固 を行う，基本的にかなり危険な要素を伴う機器 である、このような機器を安全に使用するため には通電中の生体内で，電流分布が実際どうな っているのか，あるいはより積極的に電流分布 を必要最小限に抑えるにはどうすべきかなどの 検討を行うことが重要である.

双極式電気メスに挍いて，高周波電流の供給 源を接地から完全に分離することができれば， これがその1つの解決策になるといえよう。 た従来の単極式メスにおいても，本来の対極板 を介しての帰路から電流が $100 \%$ 回収され，そ れ以外の経路に漏れる電流をなくすことが，火 傷や他の $\mathrm{ME}$ 機器への電磁的影響を減ずるため に重要である。この点から考えて出力回路のフ ローティングには，もっと関心がもたれるべき である、しかし高周波電流の分流については， わずかな浮遊容量や，リード線の絶縁物を通し ての大地への結合容量などの影響を大きく受け るので，これらの問題に適切に対処するために は，装置の一部分ごとの改良を考えていたので は不十分で, 出力トランス，出力コード，対極 板メスホルダなど総合して漏れ電流が減少す る設計が望まれる。

また現在の電気メスでは高周波電力の供給部 が非常に重く，取扱いよいとはいえない。スイ ッチング・レギュレータなど, 小型軽量で大電 力を供給できる方式が常識化しつつあるにもか かわらず，トランジスタ方式の装置であっても 内蔵の電源変圧器は極端に重い。さらに一般に は，相変らず大型の真空管や回路素子が使用さ

* 東京大学医用電子研究施設
れて抢り，高周波電力回路や電源変圧器など， 出力電力に比べて熱設計の上で大型にすぎるき らいがある。これは安全性の観点から余裕をと るといらことよりは，むしろ回路内で無䭾に消 費される電力が大きすぎるからであり，電力効 率最大にする努力すら，一般には行われてい ない。とくに高周波電流波形々切開・凝固能力 の関係が十分に検討されないまま，経験的に機 器の開発が行われたため, 効率の向上の点から 波形の検討が行われていない.

以上に述べたとおり，現在の電気メス装置に は，種々の面からみてまだ問題点が多い，以下 ではそのひとつの解決法として，われわれの開 発してきた双極メスを紹介し，とくにそれに対 応する電源の設計について検討した結果を報告 する.

通常の単極メスでは，メス刃先から加えられ た高周波電流は，電流密度こそ低下するもの の，生体を介して対極板に至り，不必要な電流 分布を形成する，これに対し，双極メスでは 2 つの成の閒にのみ電流が流れるので，電流分布 は刃先付近に局限され，広いひろがりをみな い:このことは双極メスのほらが，万一の場合 にも安全かつ他の $\mathrm{ME}$ 機器に影響を与えないと いうことになる。しかし双極メスでは 2 枚の刃 が同時に生体に接する必要があるため，一般に 放電がぎこちなく，それだけ扱いにくくなる。 “切れ味”のよい，扱いやすい双極入スを作るた め, 刃先の形状について改良が加えられ，従来 のメス刃に $2 \sim 3 \mathrm{~mm}$ の閒隙を执いて，それよ りやや長い棒状の電極を並行に配置したものが 最も満足できることがすでに知られている.

双極入スを完全かつ有効に利用するために は，その他にも条件がある，つまり電源側が完 全にフローティングの状態にあることである。 
このためにアイソレーション用トランス（アイ ソレータ）が是非必要となる。しかしアインレ 一タがいか汇完全であっても，そのあとの2 次 側の配線が長いと，結局対地容量が増加しま たこれが変動する。このため漏れ電流が増加し たり変動したりしてしまら。従ってアインレー タ以降の配線がなるべく短くなるようにした い.できればアイソレータがメスホルダーの中 に収まれば，大変都合がよい，さらに電気メス 装置全体が掌中にすっぽり入ってしまらように できないであろらか：このような意味で，まず アイソレーション用トランスをどこまで小型化 できるかの検討を行った。

まずこの理論上の限界は，コアに貯えられら るエネルギの大きさから求められよら。この観 点からコア容積 $V_{e}$ を計算すると,

$$
\mathrm{V}_{\mathrm{e}}=\frac{4 \mu_{\theta} \cdot \mathrm{P}}{\mathrm{f} \cdot \mathrm{B}^{2}} \times 10^{7} \quad\left(\mathrm{~cm}^{3}\right)
$$

ただし $\mu_{\theta}:$ コアの実效透磁率

$$
\begin{aligned}
& P \text { : 電力 }(W) \\
& f: \text { 周波数 }(\mathrm{Hz}) \\
& B \text { : 磁束密度 (Gauss) }
\end{aligned}
$$

を得る，例えば，TDK $K_{5}$ 材でトランスを作る として，磁路に空隙を設け， $\mu_{\theta} \doteqdot 100$ とし，B $=500, f=2 \mathrm{M}(\mathrm{Hz}), \quad \mathrm{P}=400(\mathrm{~W})$ で設計すれ ば, $\mathrm{V}_{\mathrm{e}}=3.2\left(\mathrm{~cm}^{3}\right)$ となる。わずか数 $\mathrm{cm}^{3}$ のコ アで 400Wの電力を伝送できるということは, 大変意外でもある.

とりあえず，従来の単極式装置を利用し，図 1のようにアイソンータを追加することを試み た.このためにやや大型の $\mathrm{EE} 60$ 型コア $\left(\mathrm{K}_{5}\right.$ 材, 大きさ $\left.60 \times 44 \times 16 \mathrm{~m} \mathrm{~m}^{3}, V_{\mathrm{e}}=27 \mathrm{~cm}^{3}\right)$ を 用い, $0.8 \phi$ フォルマル線を1次，2次とも27回 巻き，1：1の絶縁トランスを試作した１次

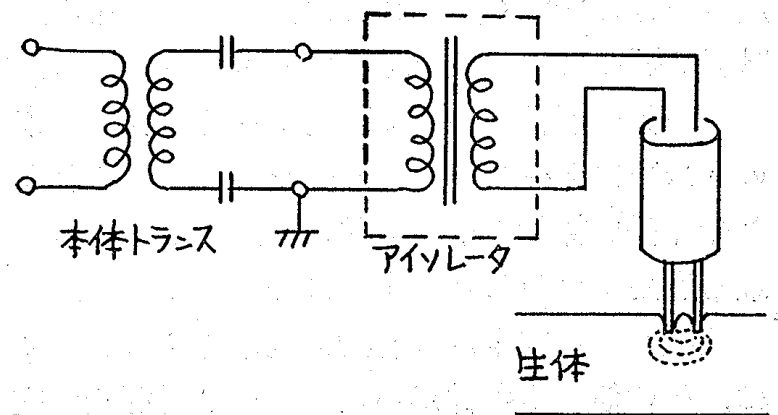

図1

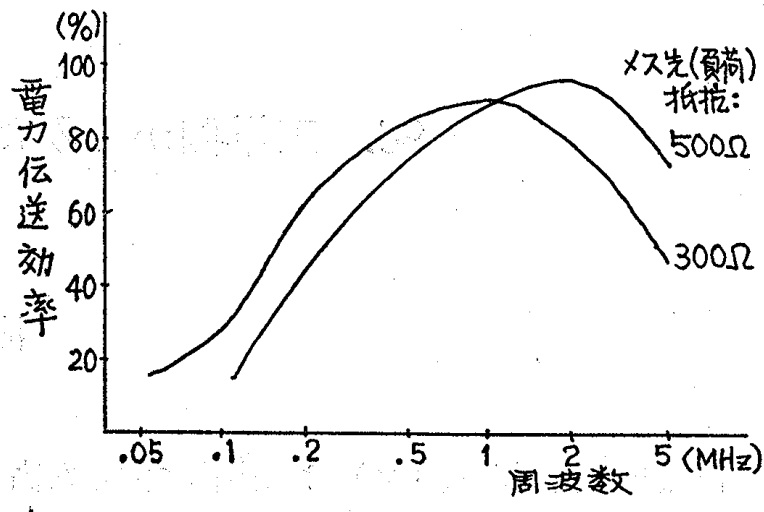

図2

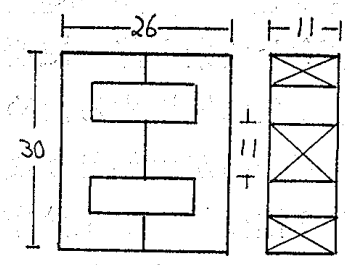

$\supset P A$

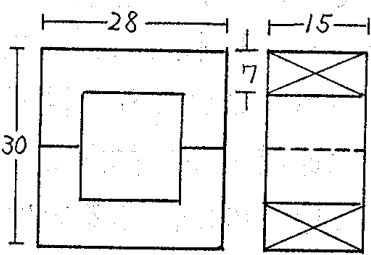

$\neg P B$ 単位 $\mathrm{mm}$

図3

表 1

\begin{tabular}{c|c|c|c|c|c|c|c}
\hline & 種類 \\
\hline 積
\end{tabular}

および 2 次巻線は一層ずつ同軸巻きにしたが, 巻線間に約 $5 \mathrm{~mm}$ 空陌を作り，巻線間容量を $14 \mathrm{pF}$ に抑えた。 1 次および 2 次の自己インダ クタンスは約 $240 \mu \mathrm{H}$ である。負荷抵抗を $300 \Omega$ $500 \Omega$ ，と想定したときのこのトランスの電力伝 送効率を測定したところ，図 2 を得た。この図 より明らかなよりに，負荷により效率が変動す るものの，設計值 $2 \mathrm{MHz}$ の付近では，80〜95\% の効率が得られることが知られる。

そこでさらにコアを小型化し，汃巻線間容 量を減少させるため，図 3 および表 1 に示す 2 種のトランスを作成した。図中のコアAは同軸 巻 (巻線間空隙 $3 \mathrm{~mm}$ )， $\mathrm{B}$ は分離巻 (巻線コア 間空隙 $2 \mathrm{~mm}$ ) とした。なおコア容積は理論的 限界值の $2 \sim 3$ 倍程度であり，試作トランズ 掌中に收まる程度の大きさである。トランスA では十分な電力伝送が行われ，トランスが過熱 することもなく，切れ味もよい。一方コアBの 形状にすれば，表 1 に示したように巻線間容量 
が著しく減少し，わずか $3 \mathrm{pF}$ 程度に抑えるこ とができるので, 漏れ電流が実際上無視できる 程度になり，双極メスとしての性能 が向上す る. 乙か乙電力伝送效率は，30\%以下になって しまう。これは結合係数の低下のためであり， トランス内で損失となっているわけではないの で， 1 次側巻線に直列に共振容量を㨉入し， 2 次側開放または適当なインピーダンスの条件で
共振をとれば，電力効率を $80 \%$ 程度まで向上す ることができ，実際の使用に耐えるようになる が，共振の Q が負荷により大きく変化するた め，いわゆる“腰の弱い”放電状態となる。この 点の改善も含め, さらに電源回路全体をメス木 ルダーの中に収容することを目標として，小型 化の検討を行っている.

\section{7. 容量結合型電気メス対極板の装着境界現象の研究}

\section{研究目的}

容量結合型対極板 (capacitive-coupling dispersive electrode) は, 導電体の金属性対極板 表面を誘電体薄膜でコーティングしたもので, 対極板と生体間が近似的にコンデンサの役割を 果たし，対極板接触面積が減少しても装着部位 に流水る高周波電流密度の増加を極力抑えてい るため，導電型対極板 (conductive dispersive electrode）で生じていた対極板接触面積の減少 に伴う熱傷問題を解決している。また容量結合 型対極板の誘電体薄膜により，值流・低周波帯 域の電流を流しにくくしているため，漏れ電流 も少なく, ママクロショックや他の $\mathrm{ME}$ 機器の干 涉も少ない1，2).

このように容量結合型対極板は, 導電型対極 板に比べて優れた特徵をもっているが，容量結 合型対極板の電気的特性を知らずに使用すると 危険な場合がある ${ }^{3)}$.

本研究は装着境界面（容量結合型対極板と皮 膚装着部位間）に導電性物質や絶縁性物質が偶 然または不慮にして流入した時の現象を把握す るために，模擬実験により確かめたものであ る. その結果，容量結合型対極板之導電型対極 板の装着境界状態に関する使用上の相違を明確 にすることができたので報告する。
酒井順哉*大山 満*
方 法

容量結合型対極板と生体間の装着境界面の電 気現象を把握し特性を解析するために，生体の 等価静電容量を無視して等価抵抗である純抵抗 Rだけで近似し，装着境界面の状態変化を電気 的に考察することを試みた。

装着境界面の状態は, 境界面に流入または固 定された各種添加物の導電率 $\sigma$ と比誘電率 $\varepsilon^{\prime}$ に よって左右されることが，予備実験と理論式か ら予想された ${ }^{3)}$ ，そこで 表 1 のごとく， case-1 (装着境界面が高絶縁物で覆われた時)， case-2 （装着境界面に尊電性物質が流入した時）， case -3（装着境界面が高誘電体で覆われた時）の 3 種に分類し，Fig. 1 の実験回路で電気的特性を 比較した。

実験回路の容量結合型対極板には Non/Gel electrode (Neomed 社) を使用し， R は無誘導 抵抗 (noninductive resistance; $400 \Omega$ ) で生体

表 1 容量結合型対極板の装着境界状態の分類

\begin{tabular}{|c|c|c|c|c|c|}
\hline 3 & 装着境界の添加物望 & 状懸 & 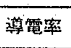 & 比唀電率 & 请 \\
\hline $\begin{array}{c}\text { コントロール } \\
\text { (正常使用) }\end{array}$ & 添加物なし & dry & \multirow{2}{*}{$\approx 0$} & \multirow{2}{*}{$\begin{array}{l}=1 \\
\text { 小 }\end{array}$} & $e x-1$ \\
\hline case-1 & イソジン (dry) & dry & & & $e x-2$ \\
\hline \multirow{2}{*}{$\operatorname{case}-2$} & 尊察性ゲル & \multirow{2}{*}{ wet } & \multirow{2}{*}{ 大 } & \multirow{2}{*}{$=0$} & $e x-3$ \\
\hline & 生理食塩水 & & & & ex-4 \\
\hline \multirow{2}{*}{ case -3} & インジン (wet) & \multirow{2}{*}{ wet } & \multirow{2}{*}{ 小 } & \multirow{2}{*}{$\mathbb{\$}_{1}^{t}$} & $e x-5$ \\
\hline & 隇菌蒸留水 & & & & $e x-6$ \\
\hline
\end{tabular}

* 鹿児島太学中央手術部 